\title{
PRIMARY TORSION OF THE OMENTUM
}

\author{
PRIMMER OMENTUM TORSIIYONU
}

\author{
Ahmet Emin YEĞIINBOY \\ Mehmet Emin BƯYƯKERKMEN \\ Atilla ÇÖKMEZ
}

\section{SUMMARY}

A 52 years old man with primary torsion of the omentum which is a rare cause of acute abdomen has been treated succesfully with total omentectomy.

(Key Words: Emergency, Infarction of Omentum, Omentectomy, Surgery)

\section{ÖZET}

Akut karının ender nedenlerinden biri olan primer omentum torsiyonlu 52 yaşındaki erkek hasta total omentektomiyle sağlığına kavuşmuştur.

(Anahtar Sözcükler: Acil, Cerrahi, Omentum, Omentum Nekrozu)

Başkent University Zübeyde Hanım Hospital (Op.Dr.A. E

Yeğinboy, M.D.) K.Yaka- IZMiR

SSK Afyon Hosp. (Op.Dr.M. E Büyükerkmen)

Atatürk State Hosp. I. Dept. of Gen Surg (Op.Dr.A Çökmez)

IZMiR

Yazışma: Dr.A E Yeğinboy 
Primary or idiopathic torsion of the omentum is one of the uncommon causes of the acute abdominal pain. It was first described by Eitel in 1899, and since then less than 250 cases have been reported in the literature $(1,2)$.

Male patient (MÖ) submitted to Afyon SSK Hosptal, 52 years old, suffering from abdominal pain, had intestinal obstruction and distention. In physical examination, he was obese. diffuse abdominal pain and rebound tenderness was present, bowel sounds were diminished. Labarotory findings; serum glycose $100 \mathrm{mg} \%$, urea $35 \mathrm{mg} \%$, $\mathrm{Hb} 86 \%$, Leukocyte $19600 / \mathrm{mm} 3$. In $\mathrm{x}$ ray examination of the abdomen: multipl hydroaeric levels were found in both intestinal and colonic localization.

Urgent laparotomy was performed with median incision. In exploration it was observed that omentum majus has been strangulated and rotated on its own axis in counter clockwise pattern. This mass had compression over the transverse colon (Fig. 1). Free sterile serosanguineous fluid was present in the peritoneal cavity. Total omentectomy was done and the patient has fully recovered and dicharged at the 7 . th day postoperatively. the pathologic diagnosis wass hemorrhagic necrosis of greater omentum.

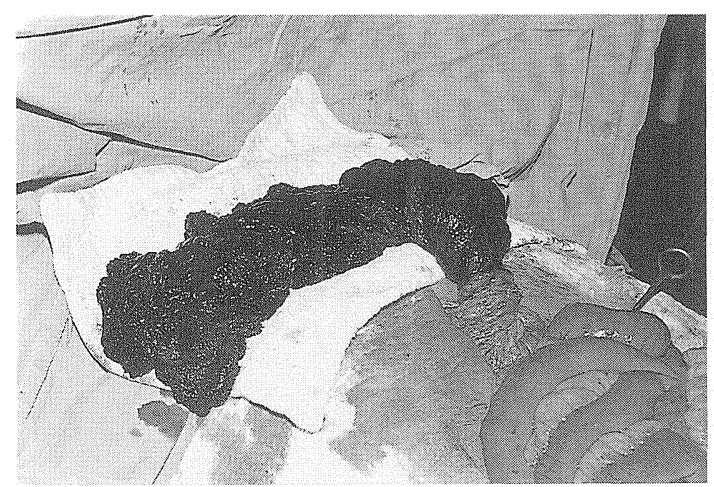

\section{DISCUSSION}

Torsion is defined as twisting, and when aplied to abdominal organs or tumors, it implies the rotation of all or part of the affected structure upon it self with the formation of a narrow neck or pedicle. To become clinically apparent, the twisting must cause some degree of circulatory embarrassment (1).

Torsion of the greater omentum may be primary or secondary, where there is some definite aetiologic factor (3). Secondary torsion, which is much more common than the primary type, is associated with adhesions of the free end of the omentum to cysts, tumors, foci of intra- abdominal inflammation, postsurgical wounds or scar, or to internal hernias or external hernia sacs (4). The pathogenesis of primary torsion is obscure. Leitner and associates (5) grouped the possible aetiologic causes into predisposing factor and precipitating factors. Predisposing factors include: 1- Anatomic variations such as tongue- like projections from the free edge of the omentum or bifid omentum; 2- Obesity causing irregular distribution of fat within the omentum; and 3- Arrangement of omental blood vessels (with venous redundance relative to the omental arterial blood supply, the larger and more tortuous omental veins allow for venous kinking and thus a point of fixation arround which cause displacement of the omentum. These include: 1- Trauma such as blunt trauma to the abdomen, violent exercise, coughing, or straining; $2-\mathrm{Hy}$ perperistalsis as with overeating causing an increase in passive movements of the omentum; and; 3- Acute changes in body position producing sudden displacement of the omentum.

When torsion occurs, the omentum twist a variable number of turns arround a pivotal point usually in a clockwise direction (4). In our patient the greater omentum has been strangulated and rotated on its own axis in counter clockwise pattern. As a result of the torsion, the segment of affected omentum becomes infarcted; If it is left untreated, it 
way from a fibrous all surrounded by adhesions; it way become infected, or it may separate to from o loose body within the abdominal cavity $(1,2)$.

Primary omental torsion usually occurs in the fourth or fifth decades of life. Males are affected twice as frequently as females and the majority of patients are overweight (4). Our patient was also 52 years old and male. Clinically, torsion of the omentum is difficult to diagnose preoperatively. The primary complaint is abdominal pain. Nausea and vomiting have been reported in about half of the cases. Fever rarely exceeds nor$\mathrm{mal}$ and the leukocyte count is usually increased moderately to a range of 12000 to 15000 per $\mathrm{mm}^{3}(1,4)$. Our patient had diffuse abdominal pain and rebound tenderness. His leukocyte is increased to 19600 per $\mathrm{mm} 3$. A mobile, tender mass is noted in onethird of cases. These features may suggest acute appendicitis, cholecystitis, pancreatitis or perforated duodenal ulcer, but are not typical of those diseases $(3,4)$.

The lesions is not usually diagnosed until discovered at laparotomy for an acute abdominal emergency, so that it is wise to explore the omentum if the suspected acutely inflamed appendix is normal. The free sterile serosanguineous fluid in the peritoneal cavity is almost always present. The twisted and strangulated omentum should be completely excised $(3,4)$.

Our patient had peritoneal serosanguineous fluid in peritoneal cavity as well, and total omentectomy provided complete recovery.

\section{REFERENCES}

1. Adams JT. Primary torsion of the omentum. Am J Surg 1973; 126:102

2. Schwartz SI, Shires GT, Spencer FC, Storer EH. Principles of Surgery 4 th ed. Singapore McGraw- hill Book Company. 1985; 1424- 25.

3. Schwartz SI, Ellis H. Maingot's Abdominal Operations. 8 th ed. Norwalk, Connecticut Appleton- CenturyCrofts; 1985: 457-8.

4. Crofoot DD. Spontaneus segmental infarction of the greater omentum. Am J Surg 1980; 139:262

5. Leitner MJ, Jordan CG, Spinner MH, Reese EC. Torsion, infarction and hemorrhage of the omentum as a cause of acute abdominal distress. Ann Surg 1952; 135:103 